Jurnal Ilmu Keolahragaan Vol. 17 (2), Juli-Desember 2018: 28 - 35

\title{
ANALISIS TINGKAT KECEMASAN (ANXIETY) DALAM MENGHADAPI PERTANDINGAN ATLET SEPAK BOLA KABUPATEN BANYUASIN PADA PORPROV 2017
}

\author{
HENGKI KUMBARA ${ }^{1}$ YOGI METRA ${ }^{2}$ ZULPIKAR ILHAM ${ }^{3}$
}

\begin{abstract}
Abstrak : Kecemasan menjadi situasi yang tergambar sangat jelas saat menjelang pertandingan, kecemasan tentu menjadi alasan terhadap buruknya performa atlet dilapangan, situasi demikian terjadi pada atlet sepak bola Kabupaten Banyuaisn menjelang Porprov 2017 di Palembang. Tujuan penelitian adalah untuk mengetahui faktor apa saja yang menyebabkan munculnya kecemasan (Anxiety), berapa besar tingkat kecemasan (anxiety) atlet sebelum bertanding. Metode penelitian yang digunakan dalam penelitian ini adalah kualitatif dan kuantitatif. Sampel penelitian berjumlah 20 orang. Teknik pengumpulan data dilaksanakan dengan observasi, kuisioner dan dokumentasi. Teknik analisis data penelitian menggunakan deskripsi persentase. Berdasarkan analisa hasil yang telah di bahas maka penelitian ini memberikan kesimpulan bahwa kecemasan disebabkan oleh kompetitif anxiety, kognitif anxiety dan somatic anxiety. Sebesar $63 \%$ atlet mengalami kecemasan sebelum bertanding dan $37 \%$ siswa tidak mengalami kecemasan sebelum bertanding baik dari aspek kompetitif anxiety, kognitif anxiety dan somatic anxiety.
\end{abstract}

Kata Kunci : Anxiety menjelang pertandingan

\section{PENDAHULUAN}

Sepak bola adalah jenis permainan beregu yang mewujudkan semua gerakan ada di dalamnya. Keinginan untuk menang agar setiap penonton merasa puas selalu ada di dalam diri setiap pemain. Hasrat yang begitu besar, dorongan dari pelatih, manajemen serta setiap elemen yang ada dilingkungan pertandingan memunculkan gaya baru dari performance seorang atlet. Meskipun keinginan untuk menang begitu besar, tetapi bagi sebagian atlet kadang kala prilaku sosial yang ada pada lingkungan pertandingan, misalnya tuntutan pelatih, tuntutan penonton, manajemen dan seluruh rangkaian animo pertandingan kadang kala sangat mengganggu psikologis dari atlet tersebut. Sehingga tidak jarang, beberapa atlet memunculkan reaksi psikologi misalnya gejala emosi, marah, senang serta cemas.

Seorang atlet sepak bola harus dapat memanajemen dengan baik seluruh reaksi psikologi yang muncul pada saat pertandingan berlangsung, hal tersebut akan sangat berdampak pada situasi pertandingan. Hal yang paling baik adalah bagaimana seorang pemain dapat merubah reaksi negatif dari pengaruh psikologi atlet menjadi kebutuhan positif. Kecemasan misalnya, dalam ilmu psikologi kecemasan atau (anxiety) di artikan sebagai bentuk reaksi psikologi yang muncul terhadap segala sesuatu yang baru. Cemas adalah situasi dimana keadaan fisiologi tubuh seolah-olah tercekik, sehingga memunculkan detak jantung yang berlebihan akibat reaksi yang baru saja muncul. Kecemasan jika tidak dikelolah dengan baik, maka akan sangat berdampak pada performa atlet khususnya atlet sepak bola, menyebabkan kekauan gerak, keadaan gemetar, takut kalah sehingga keadaan pemain tidak dapat menjalankan semua teknik yang telah dikuasai sebelumnya.

Kabupaten banyuasin telah lama menyiapkan atlet sepak bolanya untuk bertanding pada Porprov 2017 di Kota Palembang. Dalam beberapa situasi pertandingan kalau ditinjau dari faktor psikologi pertandingan, sepertinya terdapat beberapa gejala yang berkaitan dengan reaksi kecemasan. Beberapa reaksi kecemasan yang muncul diantaranya adalah terjadinya beberapa

\footnotetext{
${ }^{1}$ Penulis adalah Staf Edukatif Pendidikan Olahraga FKIP Universitas PGRI Palembang

${ }^{2}$ Penulis adalah Staf Edukatif Pendidikan Olahraga FKIP Universitas PGRI Palembang

${ }^{3}$ Penulis adalah Staf Edukatif Fakultas Ilmu Keolahragaan UNIMED
} 
Hengki Kumbara, Yogi Metra, Zulpikar Ilham: Analisis Tingkat Kecemasan (Anxiety) Dalam Menghadapi Pertandingan Atlet Sepak Bola Kabupaten Banyuasin Pada Porprov 2017

kesalahan yang disebabkan oleh kendala fisiologis tubuh seperti bergetarnya bagian anggota gerak bawah seperti tungkai, kesalahan-kesalahan teknik yang semestinya tidak perlu terjadi dikarenakan saat latihan semua teknik tergolong baik. Gejala seperti ini sangat mungkin disebabkan karena reaksi kecemasan yang datang saat bertanding, apalagi gelajanya muncul saat menit-menit awal pertandingan dimulai. Jantung berdebar dengan sangat kencang, sementara emosi terlalu cepat muncul. Untuk membuktikan apakah performa tersebut benar disebabkan karena faktor kecemasan, maka peneliti berkeinginan untuk melakukan studi analisa tingkat kecemasan yang dimiliki oleh masing-masing atlet yang akan bertanding pada Proprov 2017 di Kota Palembang.

ujuan dalam penelitian ini adalah untuk mengetahui (1) faktor-faktor yang menyebabkan kecemasan (anxiety) atlet dalam menjelang pertandingan muncul, (2) berapa besar tingkat kecemasan yang dimiliki oleh atlet dalam menjelang pertandingan menghadapi Porprov tahun 2017 di Kota Palembang.

\section{Definisi (Anxiety) Kecemasan}

Kecemasan atau dalam Bahasa Inggris "anxiety” berasal dari Bahasa Latin "angustus" yang berarti kaku, dan "ango, anci" yang berarti mencekik. Kecemasan adalah emosi yang tidak menyenangkan, seperti perasaan tidak enak, perasaan kacau, was-was dan ditandai dengan istilah kekhawatiran, keprihatinan, dan rasa takut yang kadang dialami dalam tingkat dan situasi yang berbeda-beda, Atkinson dalam Ardiyanto (2012: 2). Pendapat di atas menjelaskan bahwa kecemasan adalah keadaan suasana hati yang ditandai oleh afek negatif dan gejala-gejala ketegangan jasmaniah dimana seseorang mengantisipasi kemungkinan datangnya bahaya atau kemalangan di masa yang akan datang dengan perasaan khawatir. Kecemasan mungkin melibatkan perasaan, perilaku dan respon-respon fisiologis.

Gazalbha dalam Prasetya (2009: 2) menjelaskan kecemasan dapat diartikan sebagai suatu reaksi emosi seseorang. Kecemasan dapat didefinisikan sebagai manifestasi dari berbagai proses emosi yang bercampur baur yang terjadi ketika orang sedang mengalami tekanan perasaan dan pertentangan. Hal ini muncul karena beberapa situasi yang mengancam diri manusia sebagai mahluk sosial. Sedangkan Husdarta (2010: 73) mengatakan bahwa kecemasan didefinisikan sebagai suatu perasaan terhadap sesuatu yang ditandai dengan kekhawatiran. Kecemasan adalah fungsi ego untuk memperingatkan individu tentang kemungkinan datangnya suatu bahaya sehingga dapat disiapkan reaksi adaptif yang sesuai. Kecemasan berfungsi sebagai mekanisme yang melindungi ego karena kecemasan memberi sinyal kepada kita bahwa ada bahaya dan kalau tidak dilakukan tindakan yang tepat maka bahaya itu akan meningkat sampai ego dikalahkan.

Jiwo (2012: 2) dalam beberapa kasus, kecemasan adalah kondisi kesehatan mental yang membutuhkan pengobatan. Gangguan kecemasan umum (generalized anxiety disorder) misalnya, ditandai dengan kekhawatiran persisten (menetap) tentang keprihatinan besar atau kecil. Gangguan kecemasan lain seperti gangguan panik, gangguan obsesif-kompulsif (OCD) dan post-traumatic stress disorder (PTSD) - memiliki pemicu dan gejala yang lebih spesifik.

Singer dalam Supriyono (2012: 4) mendefinisikan kecemasan adalah reaksi dari rasa takut terhadap atau didalam suatu situasi. Secara lebih jelas Singer mengatakan bahwa kecemasan menunjukkan suatu kecederungan untuk mempersepsikan suatu situasi sebagai ancaman atau stressful (situasi yang menekan). Kecemasan dianggap sebagai akibat dari stress yang sanggup untuk mempengaruhi tingkah laku.

Berdasarkan beberapa pendapat di atas, dapat disimpulkan bahwa kecemasan adalah reaksi dari rasa takut terhadap atau didalam suatu situasi kondisi kesehatan mental yang membutuhkan pengobatan yang dimunculkan karena gejalan psikologi akbiat keadaan yang baru saja muncul. Gejala-gejala kecemasan biasanya ditandai dengan munculnya kekakuan, gemetar dan perasaan takut. Menurut Gunarsa (2004: 35) munculnya kecemasan ditandai dengan gejala-gejala : 1) Gejala Fisik misalnya adanya perubahan yang dramatis pada tingkah laku, gelisah atau tidak tenang dan sulit tidur. Terjadi peregangan pada otot-otot pundak, leher, perut. Terjadi perubahan irama pernapasan. Terjadi kontraksi otot setempat; pada dagu, sekitar 
Jurnal Ilmu Keolahragaan Vol. 17 (2), Juli - Desember 2018: 28 - 35

mata dan rahang. 2) Gejala Psikis misalnya terjadinya gangguan pada perhatian dan konsentrasi. Perubahan emosi . Menurunnya rasa percaya diri Timbul obsesi. Tiada motivasi

Firmansyah (2007: 13) juga menjelaskan bahwa seseorang yang mengalami kecemasan cenderung untuk terus menerus merasa khawatir akan keadaan yang buruk, yang akan menimpa dirinya atau diri orang lain yang dikenalnya dengan baik. Biasanya seseorang yang mengalami kecemasan cenderung tidak sabar, mudah tersinggung, sering mengeluh, sulit konsentrasi, dan mudah terganggu tidurnya atau mengalami kesulitan untuk tidur. Penderita kecemasan mengalami gejala-gejala seperti; berkeringat berlebihan (walaupun udara tidak panas dan bukan setelah berolahraga), jantung berdegup ekstra cepat atau telalu keras, dingin pada tangan atau kaki, mengalami gangguan pencernaan, merasa mulut kering, tampak pucat, sering buang air kecil melebihi batas kewajaran, dan lain-lain.

Munculnya kecemasan dalam diri seorang atlet pada situasi pertandingan atau sebelum menjelang pertandingan memiliki banyak indikator. Adisasmisto (2007: 93) membagi penyebab munculnya kecemasan yaitu kecemasan kompetitif (Competitif Anxiety), kecemasan kognitif (Kognitif Anxiety) dan kecemasan somatik. Kecemasan kompetitip adalah proses munculnya kecemasan dalam diri atlet yang terjadi sebagai hasil situasi kompetitif yang objektif. Kecemasan kompetitif merefleksikan perasaan atlet dimana akan terjadi kesalahan yaitu outcome yang tidak sukses atau pengalaman takut gagal yang akan dialami. Kecemasan kognitif adalah proses kognitif yang melibatkan antara menghadapi dan bereaksi serta faktor-faktor yang mempengaruhi interaksi alamiah tersebut. Kecemasan kognitif adalah persepsi subjektif atlet yang berkaitan erat dengan penilaian terhadap situasi kompetisi yang diikuti dengan respon somatik. Ada tiga prilaku indikator utama kecemasan kognitif yaitu, ekspektasi negatif, dan takut dievaluasi. Kecemasan somatik adalah keadaan fisiologi dalam merespon situasi yang menegangkan yang disadarinya. Keadaan fisiologis ini dapat membantu atau menjadi hambatan dalam pertandingan. Didalamnya ada reaksi otomatis seperti kejang perut, berkeringat dan detak jantung meningkat. Berdasarkan pendapat di atas, maka indikator yang muncul pada kecemasan seorang atlet adalah kecemasan kompetisi, kognitif dan somatik. Ketiga bentuk kecemasan di atas, akan sangat mengganggu penampilan seorang atlet dalam menghadapi situasi pertandingan.

\section{Permainan Sepak Bola}

Luxbacher (2004: 2) menyatakan bahwa "sepak bola dimainkan oleh 2 tim yang masing-masing tim mempertahankan gawangnya dan berusaha menjebol gawang lawan dengan jumlah masing-masing tim 11 orang pemain". Sedangkan Kurniawan (2010: 49) berpendapat bahwa "sepak bola adalah permainan bola yang sangat popular dan dimainkan oleh 2 tim yang masing-masing beranggotakan sebelas orang". Sutrisno (2013: 7) berpendapat bahwa "sepak bola adalah permainan yang dilakukan kesana-kemari sambil memperebutkan bola antar pemain dengan tujuan memasukan bola ke gawang dan menghindari agar bola tidak kemasukan ke gawang sendiri". Sepak bola terdiri dari 2 tim yang berlawanan, masing-masing tim terdiri dari 11 pemain dalam waktu 2 x 45 menit.

Berbicara sepak bola tidak akan lepas dari scenario pertandingan. Nilai yang sesungguhnya didapat dalam permainan sepak bola adalah adanya pada pertandingan. Begitu banyak cerita yang didapat dalam sebuah pertandingan sepak bola. Pertandingan sepak bola terkadang memberikan pesan drama yang begitu penting bagi sekelompok orang yang terlibat didalamnya. Siatuasi pertandingan yang kadang mungkin jarang terlihat pada olahraga lainnya adalah ketika semua orang memadati setiap pertandingan sepak bola yang diselenggarakan dimana-mana. Situasi ini kemudian menjadikan nilai sepak bola tidak hanya sebagai aspek pembinaan fisik semata melainkan dapat menyatukan semua kalangan tanpa memandang ras, suku dan golongan. Hal ini senada dengan pendapat Komarudin (2005: 34) mengungkapkan bahwa melalui pertandingan sepak bola seorang akan memperoleh kesempatan dan keuntungan dalam mengaktualisasikan dirinya ditengah-tengah masyarakat. Permainan sepakbola tidak hanya memberikan manfaat untuk fisik dan mental saja. tetapi juga dapat memberikan manfaat secara sosiologis bagi pelakunya. Permainan sepakbola dapat menjadi wahana dalam 
Hengki Kumbara, Yogi Metra, Zulpikar Ilham: Analisis Tingkat Kecemasan (Anxiety) Dalam Menghadapi Pertandingan Atlet Sepak Bola Kabupaten Banyuasin Pada Porprov 2017

pengembangan berbagai aspek kehidupan manusia termasuk di dalamnya adalah pembinaan sikap sosial.

Kompleksnya manfaat sepak bola membuat olahraga ini memiliki nilai komersialisasi yang tinggi. Maka wajar jika kemudian beberapa investor tidak sungkan -sungkan untuk mengivestasikan modal besar untuk sebuah club demi meraih kemenangan. Sehingga dengan cara apapun industri sepak bola benar-benar dibangun secara sistematis agar semakin banyak orang mencintai club-club tersebut. Disisi lain pemain sepak bola untuk dapat tetap eksis pada setiap pertandingan maka sudah barang tentu harus menjadi pemain nomor satu. Menjadi pemain nomor satu bukanlah perkara gampang, ada banyak hal yang harus di korbankan mulai dari waktu, tenaga, dana dan pikiran. Pemain sepak bola harus benar-benar fokus pada tahapan latihan agar mampu membuat pemain tersebut menjadi pemain nomor satu dan sebagai pemain sepak bola terkenal dan professional.

Dalam tulisannya Ringgo (2008: 14) mengatakan euphoria sepak bola pada lapangan pertandingan membuat pemain harus benar-benar maksimal dalam menunjukkan kualitasnya sebagai seorang pemain. Karena pemain yang memiliki kualitaslah akan menjadi pemain yang makin dicintai oleh semua orang dilapangan. Pernyataan di atas menggambarkan bahwa semakin bagus kualitas permainan seseorang maka peluang untuk menjadi pemain terkenal juga semakin terbuka lebar.

Berdasarkan uraian di atas maka dapat kita simpulkan bahwa euphoria pertandingan sepak bola membuat beragam cerita, tentang kebugaran fisik, ketenaran, industrialisasi dan penyatuan berbagai umat di semua kalangan tanpa memandang suku, ras, golongan dan agama. Semua berkumpul dalam sebuah tempat yaitu tempat pertandingan sepak bola di gelar.

\section{METODE}

Metode penelitian ini adalah metode kualitatif dan kuantitatif. Subjek penelitian adalah atlet sepak bola Kabupaten Banyuasin berjumlah 20 orang. Pengumpulan data menggunakan lembar observasi, kuisioner dan dokumentasi. Analisis data menggunakan deskripsi persentase.

\section{HASIL}

Munculnya kecemasan dalam diri seorang atlet pada situasi pertandingan atau sebelum menjelang pertandingan memiliki banyak indikator. Adisasmisto (2007: 93) membagi penyebab munculnya kecemasan yaitu kecemasan kompetitif (Competitif Anxiety), kecemasan kognitif (Kognitif Anxiety) dan kecemasan somatik. Kecemasan kompetitip adalah proses munculnya kecemasan dalam diri atlet yang terjadi sebagai hasil situasi kompetitif yang objektif. Kecemasan kompetitif merefleksikan perasaan atlet dimana akan terjadi kesalahan yaitu outcome yang tidak sukses atau pengalaman takut gagal yang akan dialami. Kecemasan kognitif adalah proses kognitif yang melibatkan antara menghadapi dan bereaksi serta faktor-faktor yang mempengaruhi interaksi alamiah tersebut. Kecemasan kognitif adalah persepsi subjektif atlet yang berkaitan erat dengan penilaian terhadap situasi kompetisi yang diikuti dengan respon somatik. Ada tiga prilaku indikator utama kecemasan kognitif yaitu, ekspektasi negatif, dan takut dievaluasi. Kecemasan somatik adalah keadaan fisiologi dalam merespon situasi yang menegangkan yang disadarinya. Keadaan fisiologis ini dapat membantu atau menjadi hambatan dalam pertandingan. Didalamnya ada reaksi otomatis seperti kejang perut, berkeringat dan detak jantung meningkat.

Berdasarkan teori di atas, dalam penelitian ini bahwa kecemasan yang muncul diindikasikan atas 3 aspek yaitu kompetitif anxiety, kognitif anxiety dan somatic anxiety. Untuk lebih jelasnya dapat dilihat pada tabel di bawah ini : 
Jurnal Ilmu Keolahragaan Vol. 17 (2), Juli - Desember 2018: 28 - 35

Tabel Indikator Anxiety

\begin{tabular}{|c|c|c|c|c|}
\hline \multirow{2}{*}{ NO } & \multirow{2}{*}{ INDIKATOR } & \multirow{2}{*}{ SUB INDIKATOR } & \multicolumn{2}{|c|}{ GRADASI } \\
\hline & & & YA & TIDAK \\
\hline \multirow{2}{*}{1} & \multirow{2}{*}{ Kompetitip anxiety } & Tidak Sukses & & \\
\hline & & Takut Gagal & & \\
\hline \multirow{2}{*}{2} & \multirow{2}{*}{ Kognitif Unxiety } & Ekspektaksi Negatif & & \\
\hline & & Takut di Evaluasi & & \\
\hline \multirow{3}{*}{3} & \multirow{3}{*}{ Somatic Anxiety } & Kejang Perut & & \\
\hline & & Berkeringat & & \\
\hline & & Detak Jantung Berdebar & & \\
\hline
\end{tabular}

Berdasarkan tabel di atas, dapat dijelaskan bahwa penyebab munculnya kecemasan sebelum bertanding pada atlet adalah (1) kompetitif anxiety ditandai dengan gejala-gejala takut tidak sukses dilapangan dan takut gagal dilapangan, (2) kognitif anxiety gejalanya adalah munculnya ekspektasi negatif, dan takut dievaluasi dan (3) somatic anxiety gejalanya adalah gejala fisik misalnya kejang perut, berkeringat dan detak jantung berdebar.

Berdasarkan kualitas angket/kuisioner yang telah di isi oleh responden atau dalam hal ini bagaimana tingkat kecemasan (anxiety) atlet akan di paparkan sebagai berikut :

\section{Deskripsi Persentase Tingkat Kecemasan Ditinjau Dari Aspek Kompetitif Anxiety}

Salah satu faktor penyebab yang muncul dalam diri siswa saat sebelum bertanding adalah disebabkan oleh aspek kompetitif anxiety. Berikut dipaparkan seberapa besar persentase kecemasan siswa sebelum bertanding:

Tabel Deskripsi Persentase Aspek Kompetitif Anxiety

\begin{tabular}{cccc}
\hline NO & KETERANGAN & Fa & Fr \\
\hline 1 & YA & 76 & 633,333 \\
\hline 2 & TIDAK & 44 & 366,667 \\
\hline \multicolumn{2}{c}{ TOTAL KOLOM } & 120 & $100 \%$ \\
\hline
\end{tabular}

Berdasarkan table di atas, dapat dijelaskan bahwa kecemasan siswa sebesar 63,33\% atau 76 jawaban menyatakan Ya kecemasan bersumber dari aspek kompetitif anxiety dan 36,66 atau sebanyak 76 jawaban menyatakan Tidak kecemasan bersumber dari aspek kompetitif anxiety.

\section{Deskripsi Persentase Tingkat Kecemasan Ditinjau Dari Aspek Kognitif Anxiety}

Salah satu faktor penyebab yang muncul dalam diri siswa saat sebelum bertanding adalah disebabkan oleh aspek kognitif anxiety. Berikut dipaparkan seberapa besar persentase kecemasan siswa sebelum bertanding:

Tabel Deskripsi Persentase Aspek Kognitif Anxiety

\begin{tabular}{cccc}
\hline NO & KETERANGAN & Fa & Fr \\
\hline 1 & YA & 82 & 683,333 \\
\hline 2 & TIDAK & 38 & 316,667 \\
\hline \multicolumn{2}{c}{ TOTAL KOLOM } & 120 & $100 \%$ \\
\hline
\end{tabular}

Berdasarkan table di atas, dapat dijelaskan bahwa kecemasan siswa sebesar 68,33\% atau 82 jawaban menyatakan Ya kecemasan bersumber dari aspek kognitif anxiety dan 31,66 atau sebanyak 38 jawaban menyatakan tidak kecemasan bersumber dari aspek kognitif anxiety. 
Hengki Kumbara, Yogi Metra, Zulpikar Ilham: Analisis Tingkat Kecemasan (Anxiety) Dalam Menghadapi Pertandingan Atlet Sepak Bola Kabupaten Banyuasin Pada Porprov 2017

\section{Deskripsi Persentase Tingkat Kecemasan Ditinjau Dari Aspek Somatic Anxiety}

Salah satu faktor penyebab yang muncul dalam diri siswa saat sebelum bertanding adalah disebabkan oleh aspek Somatic Anxiety. Berikut dipaparkan seberapa besar persentase kecemasan siswa sebelum bertanding:

Tabel Deskripsi Persentase Aspek Somatic Anxiety

\begin{tabular}{cccc}
\hline NO & KETERANGAN & Fa & Fr \\
\hline 1 & YA & 94 & 58,75 \\
\hline 2 & TIDAK & 66 & 41,25 \\
\hline \multicolumn{2}{c}{ TOTAL KOLOM } & 160 & 100 \\
\hline
\end{tabular}

Berdasarkan table di atas, dapat dijelaskan bahwa kecemasan siswa sebesar 58,75\% atau 94 jawaban menyatakan Ya kecemasan bersumber dari aspek somatic anxiety dan 41,25 atau sebanyak 66 jawaban menyatakan tidak kecemasan bersumber dari aspek somatic anxiety.

Memperhatikan data yang muncul pada seberan kuisioner penelitian, maka selanjutnya adalah menjawab bagaimana kecemasan atelt sepak bola sebelum pertandingan. Berdasarkan analisis data penelitian dapat dilihat pada tabel di bawah ini :

Tabel Rekapitulasi Hasil

\begin{tabular}{ccc}
\hline Keterangan & Frekuensi & Persentase \\
\hline Ya & 13 & 63 \\
\hline Tidak & 7 & 37 \\
\hline
\end{tabular}

Untuk lebih jelasnya tingkat kecemasan siswa dapat dilihat pada histogram di bawah ini :

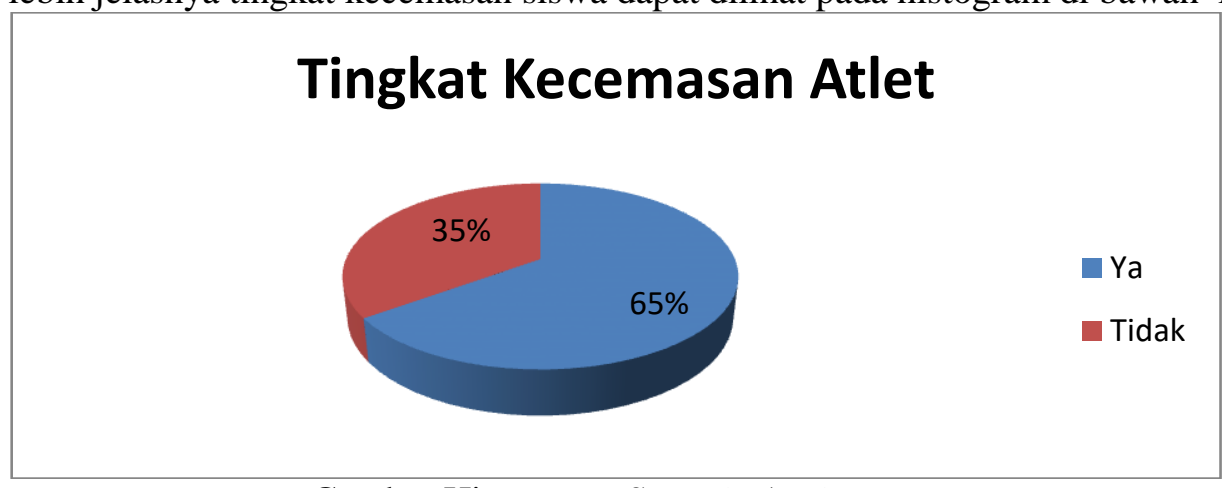

Gambar Histogram Somatic Anxiety

Berdasarkan histogram di atas dapat dipaparkan bahwa 63\% atlet atau sebanyak 13 orang mengalami kecemasan sebelum bertanding dan $37 \%$ atlet atau sebanyak 7 orang tidak mengalami kecemasan sebelum bertanding baik dari aspek kompetitif anxiety, kognitif anxiety dan somatic anxiety.

\section{PEMBAHASAN}

Hasil penelitian menyatakan bahwa $63 \%$ atlet atau sebanyak 13 orang mengalami kecemasan sebelum bertanding dan $37 \%$ atlet 7 orang tidak mengalami kecemasan sebelum bertanding baik dari aspek kompetitif anxiety, kognitif anxiety dan somatic anxiety. Melihat dari hasil yang di dapat dari penelitian di atas, maka sangat wajar jika lebih dari 50\% atau 63\% siswa menyatakan cemas sebelum bertanding. Hal tersebut karena kecemasan akan selalu datang pada keadaan atau situasi yang dianggap baru.

Kecemasan adalah emosi yang tidak menyenangkan, seperti perasaan tidak enak, perasaan kacau, was-was dan ditandai dengan istilah kekhawatiran, keprihatinan, dan rasa takut yang kadang dialami dalam tingkat dan situasi yang berbeda-beda. Kecemasan adalah keadaan suasana hati yang ditandai oleh afek negatif dan gejala-gejala ketegangan jasmaniah dimana 
Jurnal Ilmu Keolahragaan Vol. 17 (2), Juli - Desember 2018: 28 - 35

seseorang mengantisipasi kemungkinan datangnya bahaya atau kemalangan di masa yang akan datang dengan perasaan khawatir. Kecemasan mungkin melibatkan perasaan, perilaku dan respon-respon fisiologis.

Kecemasan sering kali menghantui perasaan seorang atlet, bahkan tidak hanya atlet pemula, melainkan lebih dari pada itu atlet-atlet profesional pun juga mengalami kecemasan. Kecemasan digambarkan munculnya reaksi psikologis yang dapat merubah respon fisiologis seseorang terhadap sesuatu keadaan yang baru saja dialaminya. Atlet profesionalnya biasanya tidak akan mengalami perasaan cemas dalam waktu yang lama, keadaan situasi pertandingan yang cukup lama akan membuat atlet profesional sedikit lebih baik beradaftasi.

Perasaan cemas dapat mengganggu atlet pada saat yang menentukan, misalnya pada situasi skor yang sangat tipis dan menentukan pada akhir-akhir pertandingan. Cratty dalam Adisasmito (2007: 92) menjelaskan beberapa hal yang dapat diklaisifikasikan pada kecemasan diantaranya adalah takut gagal dalam pertandingan, takut akan akibat sosial atas mutu prestasi mereka, takut kalau cedera atau mencederai lawan, takut fisiknya tidak mampu menyelesaikan tugasnya atau pertandingan dengan baik, percaya tidak percaya, ada atlet yang takut untuk menang.

Gejala kecemasan yang muncul pada atlet seharusnya disikapi dengan penuh kewaspadaan dan kecemerlangan dalam bertanding. Seorang atlet yang baik pasti akan menganggap situasi yang meneganggkan adalah hal yang biasa-biasa saja, tidak perlu merasa gugup, dan takut gagal. Perasaan tenang malah akan membuat atlet lebih nyaman merespon seluruh kejadian dalam situasi pertandingan

Situasi pertandingan adalah dimana seorang pemain menggambarkan perasaannya dengan sangat positif. Tuntutan penonton, pelatih, orang-orang terdekat agar dapat mampu memenangkan permainan menjadi daya dorong munculnya kecemasan. Hal tersebut sangatlah mengganggu baik dalam diri seorang atlet, fisiologi maupun gejala-gejala seperti mental seorang atlet.

\section{KESIMPULAN DAN SARAN}

Berdasarkan analisis data dalam penelitian ini, maka dapat disimpulkan bahwa : a) Kecemasan bersumber dari 3 aspek indikator yaitu kompetitif anxiety, kognitif anxiety dan somatic anxiety, b) $63 \%$ atlet atau sebanyak 13 orang mengalami kecemasan sebelum bertanding dan $37 \%$ siswa tidak mengalami kecemasan sebelum bertanding baik dari aspek kompetitif anxiety, kognitif anxiety dan somatic anxiety.

Beberapa hal yang perlu disarankan terkait dengan hasil penelitian di atas adalah sebagai berikut :

1. Agar atlet dapat mengurangai kecemasan sebelum bertanding dengan memperbanyak latihan-latihan kecemasan.

2. Agar pelatih semakin mampu mengetasi kecemasan siswanya sebelum pertandingan dengan menambah jam terbang dan metode latihan yang tepat untuk mengatasi kecemasan.

3. Agar pengurus cabor sepak bola dan pemerintah dapat mengurangi gejala-gejala yang dapat menimbulkan kemesan sebelum bertanding pada atlet.

\section{DAFTAR PUSTAKA}

Ardiyanto. 2012. Kecemasan pada Pemain Futsal Dalam Menghadapi Turnamen. Universitas Ahmad Dahlan Jogjakarta.

Arikunto.Suharsimi. 2006. Metodelogi Penelitian. Alfabeta. Bandung. --. 2013. Metodelogi Penelitian. Alfabeta. Bandung.

Firmansyah. 2007. Kecemasan dan High Performance. Universitas Negeri Jakarta.

Gilang.Moh. 2007. Pendidikan Jasmani, Olahraga dan Kesehatan. Ganesha; Bandung.

Gunarsah. Singgih. D. 1996. Psikologi Olahraga. Ganseha; Bandung.

Husdarta. 2010. Psikologi Olahraga.Alfabeta. Bandung.

Jiwo, Tirto. 2012. Anxiety (Kecemasa). Universitas Negeri Semarang.

Kurniawan.Feri. 2010. Buku Pintar Olahraga. Alfabeta; Bandung. 
Hengki Kumbara, Yogi Metra, Zulpikar Ilham: Analisis Tingkat Kecemasan (Anxiety) Dalam Menghadapi Pertandingan Atlet Sepak Bola Kabupaten Banyuasin Pada Porprov 2017

Luxbacher. 2004. Sepak Bola. Rajagrafindo Persada. Jakarta.

Mylsidu. 2014. Psikologi Olahraga. Alfabeta; Bandung.

Nugraha. 2012. Mahir Sepak Bola. Alfabeta; Bandung.

Nonalisa. 2011. Sepak Bola. Universitas Negeri Semarang.

Prasetya. 2009. Dampak Kecemasan Pada Atlet Bola Basket Sebelum Bertanding. Jurnal; Universitas Brawijaya Malang.

Riduan.2013. Motivasi Anggota Dalam Mengikuti Ekstrakurikul Club Sepak Bola.Universitas Negeri Semarang.

Ringgo.2008. Pertandingan Sepak Bola dan Geliat Ekonomi. Universitas Sebelas Maret.

Singarimbun, Masri. 2010. Metode Penelitian Survey. LP3S. Jakarta.

Sudarwati.Lilik. 2007. Mental Juara Modal Prestasi Atlet. Raja Grafindo Persada: Jakarta.

Sugiyono.2008, 2013, 2014.Metodelogi Penelitian. Alfabeta. Bandung.

Sukirno. 2012. Psikologi Olahraga. Unsri Perss. Palembang.

Suroto (2004).Sepak Bola. Universitas Negeri Yogyakarta.

Sutrisno. 2013. Pendidikan Jasmani, Olahraga dan Kesehatan K13. Ganesha; Bandung. 